\title{
The need for international and regional transboundary cooperation in European river basin management as a result of new approaches in $\mathrm{EC}$ water law
}

\author{
Marleen van Rijswick • Herman Kasper Gilissen • \\ Jasper van Kempen
}

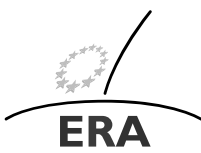

Published online: 25 December 2009

(C) The Author(s) 2009. This article is published with open access at Springerlink.com

EUROPÄISCHE RECHTSAKADEMIE ACADEMY OF EUROPEAN LAW ACADEMIE DE DROIT EUROPEEN ACCADEMIA DI DIRITTO EUROPEO

TRIER - TREVES - TREVIRI

\begin{abstract}
With the introduction of the Water Framework Directive in 2001, EC water law adopted both a governance approach and a river basin approach. These new approaches are characterised by a high level of proceduralisation and by dividing the EU territory into river basins. These characteristics emphasise the need for transboundary cooperation in water management, both on the international and the regional level. Although there is a long tradition of transboundary cooperation on the international level, this level has its difficulties and limits, which urges the need for regional transboundary cooperation in river basin management. There are several instruments available to shape cooperation at the regional level, but there is still little experience in cooperation between water management authorities at that level. After describing current transitions in EC water law, we explore some instruments and their possibilities for transboundary cooperation on both levels, with a slight tendency toward the regional level.
\end{abstract}

Keywords Transboundary cooperation - Transboundary river basin management . Water governance · European water law · Water Framework Directive · Directive on the management of flooding

Marleen van Rijswick is professor of European and Dutch water law. Herman Kasper Gilissen is a $\mathrm{Ph}$.D. candidate, researching adaptation to climate change in Dutch water management. Jasper van Kempen is a Ph.D. candidate, researching transboundary water management. They all work at Utrecht University, Faculty of Law, Economics and Governance, Centre for Environmental Law and Policy, www.centrumvooromgevingsrecht.nl. An earlier version of this paper was delivered at the Academy of European Law Annual Conference on European Water Management Law, Brussels, 23 to 24 April 2009.

M. van Rijswick (凶) · H.K. Gilissen · J. van Kempen

Faculty of Law, Economics and Governance, Centre for Environmental Law and Policy,

Utrecht University, Achter Sint Pieter 200, 3512 HT Utrecht, the Netherlands

e-mail: H.F.M.W.vanRijswick@uu.nl 


\section{Introduction}

European water law is in transition. It has developed from a highly differentiated field of law into a more coherent and integral legal domain. The Water Framework Directive (WFD) ${ }^{1}$ integrates some older water directives, which guarantees that the old protection regime will be respected. ${ }^{2}$ This transition has also brought about some new approaches in EC water law, like the river basin approach, ${ }^{3}$ following from the 1992 Helsinki Convention. ${ }^{4}$ The river basin approach is reflected both in the WFD and the Floods Directive (FD), ${ }^{5}$ and is based on an integrated protection of river basins on a national and transnational scale. Other new aspects are a stronger focus on ecology and the sustainable use of water, prescribing an integrated protection of ecosystems as a whole, more attention to the ecological protection of the aquatic environment, the relationship with other policy fields like nature, product policy, agriculture, and even spatial planning and a greater role for financial or economic instruments and public participation. Finally, new European directives are an example of a governance approach with a focus on proceduralisation, flexibility and policy discretion for the Member States.

This new approach seems a big step forward in European water management, especially when it comes to new challenges in water management like the protection of ecosystems, dealing with the effects of climate change and the transnational management of European waters. However, it also becomes clear that some goals are difficult to achieve for individual Member States, when measures are necessary in policy fields that are fully harmonised by the EC, or in the case of transboundary effects. Especially the river basin approach leads to shared responsibilities between Member States in one transboundary river basin. EC law lays down obligations for the Member States individually, for directives are binding as to the results to be achieved by each addressed Member State. ${ }^{6}$ This correlation between shared responsibilities and individual obligations emphasizes the need for (more) structural transboundary coop-

\footnotetext{
${ }^{1}$ Directive 2000/60/EC of the European Parliament and of the Council of 23 October 2000 establishing a framework for Community action in the field of water policy, OJ L327/1.

${ }^{2}$ The main purpose of the WFD, in short, is to establish a framework for the protection of inland surface waters, transitional waters, coastal waters and groundwater (Article 1 WFD). The WFD stipulates environmental objectives aimed at achieving a 'good status' of surface waters and groundwater (Article 4.1 WFD).

${ }^{3} \mathrm{~A}$ river basin is the area of land from which all surface run-off flows through a series of streams, rivers and, possibly, lakes into the sea at a single river mouth, estuary or delta (Article 2.13 WFD).

${ }^{4}$ The Convention on the Protection and Use of Transboundary Watercourses and International Lakes, done at Helsinki on 17 March 1992. In force on 6 October 1996; 31 ILM 1312 (1992). The WFD is to contribute to the implementation of Community obligations under international conventions on water protection and management, notably the Helsinki Conference (Paragraph 35 Preamble WFD).
}

${ }^{5}$ Directive 2007/60/EC of the European Parliament and of the Council of 23 October 2007 on the assessment and management of flood risks, OJ L 288/27. The main purpose of the Floods Directive is to establish a framework for the assessment and management of flood risks, aiming at the reduction of the adverse consequences for human health, the environment, cultural heritage and economic activity associated with floods in the Community.

${ }^{6}$ Article 249 EC Treaty. 
eration. ${ }^{7}$ EC water law contains a general obligation for Member States to cooperate in Article 3.4 WFD. ${ }^{8}$ Still, EC water law does not prescribe any concrete instruments to shape this cooperation. Neither does it contain any provisions to collectively hold Member States responsible for achieving the results in an international river basin district. Nor does it provide for exemptions if the results are not achieved by a Member State because of certain acts or omissions by another (Member) State. This unfortunately leads to the conclusion that EC water law nowadays does not itself provide for a satisfactory solution to one of the major problems in European water management: transboundary pollution and the transboundary effects of flood risk management.

To meet the objectives of modern EC water directives, Member States should cooperate successfully, and they should initiate and eventually structure this cooperation themselves. Possibilities for formal international or regional transboundary cooperation do exist, but these are almost left unused, especially the possibilities for regional transboundary cooperation. An important condition for successful cooperation is that Member States should have the same points of departure, mainly concerning the way in which to deal with complexity and policy discretion, as well as ambitions and the legal value of obligations deriving from EC water law. Nowadays, many differences still exist, which seems to be a suppressing factor for successful transboundary cooperation in water management. ${ }^{9}$ Harmonization is one of the main objectives of EC law and it is also necessary in EC water and environmental law.

We will explore two different levels of transboundary cooperation that can be used to shape this cooperation: cooperation on a state or international level as well as cooperation on a regional level. ${ }^{10}$ To meet the objectives of modern EC water directives, cooperation should take place at both levels as it is a linear process that needs continuous interaction between all the parties involved across and within borders at all relevant (administrative) levels. The first level is the international level, at which socalled watercourse conventions have been or could be concluded. The accompanying structures mostly stem from multilateral (or occasionally bilateral) conventions, and are solely meant for cooperation between state actors. Within the Community, this level is mostly suitable for inter alia coordinating the implementation of EC water law, setting goals and standards, drafting and coordinating river basin management plans, drafting and coordinating programmes of measures, and the use of exemptions (if any are available). ${ }^{11}$ In general, at this high political level of transnational water management, policy is mostly made, but few or no concrete measures are actually taken.

The second level is the regional level. The accompanying structures mostly stem from bilateral or trilateral conventions, secondary EC law, and other kinds of formal and informal agreements and are meant for cooperation between regional authorities,

\footnotetext{
${ }^{7}$ See Keessen/Van Kempen/Van Rijswick [12].

${ }^{8}$ The obligation to cooperate is not new in EC water law. Before the WFD, a comparable obligation could be found in, for example, Article 4 of the Swimming Water Directive (76/160/EEC).

${ }^{9}$ See Uitenboogaart/Van Kempen/Wiering/Van Rijswick [26].

${ }^{10}$ Extensively on transboundary cooperation on both levels Gilissen [6].

${ }^{11}$ But also problems and restrictions occur at this level (see Sect. 4.2).
} 
including water management authorities. ${ }^{12}$ This is mostly suitable for cooperation in water management at a practical level, i.e. the final phase of taking concrete measures and other management actions in transboundary water systems. A lack of cooperation at this level might lead to the undesirable and uncertain situation where (high-level) transboundary water management policy does exist, but might never be executed in practice.

The structure of this article is as follows. The article deals with the question of the role of transboundary cooperation in river basin management in the new era of EC water legislation. After the introduction above, in Sect. 2 we will give three examples of cases within the river basins of the Rhine, the Meuse and the Danube, which illustrate the need and the desire for transnational cooperation. Section 3 deals with some main changes in the governance of EC water management. Proceduralisation, the consequences of the chosen river basin management approach, and the differences in the implementation of the Water Framework Directive in several Member States will be briefly discussed before we focus on several methods of transnational cooperation. Section 4 deals with cooperation on the international level and its difficulties and limits. Section 5 discusses several possibilities for cooperation at the regional level. The regional cooperation within the river basins of the Meuse and Rhine will be taken as an example, more in particular the experiences in cooperation between Belgium, Germany and the Netherlands. Special attention will be given to the new Regulation on European Grouping of Territorial Cooperation, being a new and challenging instrument for transboundary water management. We will finish with some concluding remarks on our research question.

\section{Three examples of water management that are in need of transnational cooperation}

To give an idea of the problems that have to be tackled in daily life, we will give three examples of cases that demonstrate the need for transnational cooperation.

\subsection{The Dommel ${ }^{13}$}

The Dommel is a small transnational river within the Meuse basin district and it flows from Belgium (Flanders) towards the Netherlands. On both sides of the border there are zinc factories belonging to the same company. The directive concerning integrated pollution prevention and control (IPPC directive) and the Dangerous substances directive ${ }^{14}$ regulate the factories and both directives ${ }^{15}$ have been transposed

\footnotetext{
${ }^{12}$ Of course, these conventions have been concluded by States, but their aim is mainly to create some possibilities for transboundary cooperation between regional authorities.

${ }^{13}$ The case of the River Dommel is currently being researched by J.J.H. van Kempen, Ph.D. candidate at Utrecht University, Centre for Environmental Law and Policy.

${ }^{14}$ See Directive 2006/11/EC of the European Parliament and of the Council of 15 February 2006 on pollution caused by certain dangerous substances discharged into the aquatic environment of the Community. ${ }^{15}$ See Directive 2008/1/EC of the European Parliament and of the Council of 15 January 2008 concerning integrated pollution prevention and control.
} 
into the national laws of Flanders and the Netherlands. On the Dutch side of the border, the requirements in the environmental licence are much more stringent than on the Belgian side. Both countries state that their environmental requirements are in accordance with the IPPC directive, especially that the emission standards are based on the best techniques available. There are discharges of wastewater with dangerous substances from the Belgian factory into the River Dommel very near to the border. The polluted surface water flows into the Netherlands where the regional water authority has great problems in complying with environmental standards for surface water due to these discharges. In the Netherlands it is the regional water authority that is responsible for the integrated water management of regional waters and which is responsible - according to the Dutch national legal system-for meeting the goals of the Water Framework Directive. Cooperation using the Meuse Treaty is not the best option, because the Treaty is mainly meant for cooperation between Member States on a central level. For regional water management, cooperation on the basis of treaties is less suitable. Cooperation within transnational regional and often smaller waters requires other kinds of cooperation.

\subsection{The Rába case ${ }^{16}$}

The Rába case concerns the pollution of a transnational river in Austria and Hungary, both EU Member States. The river is one of the most natural and free-flowing rivers in Hungary providing habitat for various flora and fauna. Fisheries and ecotourism are important. The river is part of the Danube river basin. It is polluted by substances which cause a layer of foam on the surface water. The substance that causes the foam is naphthalene-sulphonate, a so-called surfactant. It is discharged by Austrian tanneries. The substance is not regulated under EC environmental law (Directive 2006/11/EC) because the substance is not on list I or II. The tanneries are IPPC installations but in the BREF documents the surfactant is listed as a tanning agent that can be used in a tannery and it is not listed as one that should be substituted. Nevertheless, it causes damage to the environment, mainly because it harms algae and smaller animals in the food chain. Furthermore, the tourism sector suffers damage caused by the pollution. There is good cooperation between Austria and Hungary on this matter and the question has been discussed in the European Parliament. Unfortunately the Daughter Directive with environmental quality standards for surface waters (2008/105/EC)—called the Lex Rába by the Hungarians, because they hoped that this directive would regulate the problem-does not set quality standards for this substance. EC law could not offer a proper solution in this case, nor could international law. Informal cooperation led to the solution where the Austrian authorities prescribed extra filtering measures in the environmental licences for the tanneries.

\subsection{The Rhine}

The third example concerns the protection of the Rhine River Basin District against flooding. The Rhine is a vulnerable river catchment area in the case of climate change,

${ }^{16}$ We have used the information for this case as described in Wellman [29]. 
for example due to winter precipitation, snowmelt from the Alps, the large discharges into the Rhine, many people living in the surrounding area and industry which is situated in the river basin district. There was severe flooding in 1993, 1995, 1999, and 2007. Nine Member States as well as non-Member States cooperate to protect the area from flooding. There is great dependence between measures taken upstream and flooding downstream and between spatial planning/land use and flood mitigation measurements like the Dutch 'more room for the river' programme and the building of dikes. There is close cooperation within the Rhine Convention and the Rhine Committee and on an informal basis, partly financially supported by the EU.

\section{EC water law in transition: the role of transboundary cooperation}

The main purpose of the WFD, in short, is to establish a framework for the protection of inland surface waters, transitional waters, coastal waters and groundwater. ${ }^{17}$ The WFD stipulates environmental objectives aimed at achieving a 'good status' of surface waters and groundwater. ${ }^{18}$ The purpose of the Floods Directive is to establish a framework for the assessment and management of flood risks, aiming at a reduction of the adverse consequences for human health, the environment, cultural heritage and economic activity associated with floods in the Community. ${ }^{19}$

The 'good status' of surface water has to be achieved by the Member States through producing river basin management plans for each river basin district within their territory. In order to achieve the objectives established under Article 4 WFD, they are also obliged to establish a programme of measures for each river basin district within their territory. ${ }^{20}$ The objectives of the Floods Directive have to be achieved by the Member States in three successive steps, namely the undertaking of preliminary flood risk assessments; the preparation of flood hazard maps and flood risk maps; and in the end the establishment of flood risk management plans. ${ }^{21}$

The role of transnational cooperation will be of more significance due to the new approach in European water management, as mentioned before. In this section we will describe some aspects of this new approach.

\subsection{Proceduralisation}

It is stated in the legal literature that there is a greater focus on proceduralisation in EC water law. ${ }^{22}$ This may be the result of a governance approach. That is certainly the case with the Directive on the protection against flooding but one could see this tendency also in the Water Framework Directive. Examples are the setting of (ecological) goals, the planning system, the role of the Common Implementation Strategy

\footnotetext{
${ }^{17}$ Article 1 WFD.

${ }^{18}$ Article 4.1 WFD.

${ }^{19}$ Article 1 Floods Directive.

${ }^{20}$ Articles 13 and 11 WFD.

${ }^{21}$ Articles 4, 6 and 7 Floods Directive.

${ }^{22}$ See amongst others: Howarth [11]; Scott [21]; Lee [14], p. 163; Van Rijswick [28].
} 
and the impact of public participation in the goal setting and planning process. Proceduralisation leads to a less clear division of powers. The administration works closely together with the national legislators and the role of the European Parliament thereby diminishes.

It is also argued that this more procedural approach leads to the fact that the Water Framework Directive now contains obligations of best efforts or obligations concerning means to attain the environmental objectives contained in Article 4, instead of obligations to attain specific results that follow from the older water directives.

How must we deal with this new approach from a legal point of view? Will the ambitious goals and objectives be attained? Will water management in Europe improve and will we manage to have a sustainable use of our water resources? Will there be a fair sharing of the profits and burdens throughout the whole river basins? What will it mean if we agree to the statement that the WFD only requests the Member States to follow the correct procedures, to take measures that are part of the programmes of measures and to make a proper use of the exemptions by providing good justifications? It is stated by Krämer that this new approach of Framework Directives and proceduralisation is a result of a stronger Anglo-American influence. ${ }^{23}$ A decision that is taken in conformity with an agreed procedure should lead to a good decision: if the procedure is good, the decision is also good. Will the Court of Justice only look whether all the necessary steps in the prescribed procedure have been taken in the right way? That is the way the Dutch Council of State looks at government decisions when the authorities have a great deal of policy discretion. We are not yet fully convinced that this new approach alone will lead to a better protection of water systems and that the goals of the new European water directives can be achieved. If we look at the implementation process in, for example, the Netherlands and England and Wales we see that right from the beginning all exemptions will be used. ${ }^{24}$ Achieving the good status under the Water Framework Directive will be at the earliest in 2027. What will it mean if all upstream states in a river basin decide the same? How can downstream countries ever fulfil their obligations on time? And what instruments do they have to request more measures upstream?

A procedural approach may be logical for water management on islands like the United Kingdom. There are no transnational river basins and all the consequences remain within the Member State. But even then there are interests of citizens and nature that need to be protected. On the continent, with its transnational river basins, using only a procedural approach may lead to an unfair balance of profits and burdens within river basins. In our point of view an ultimate goal and environmental objectives, further elaborated in quality standards by means of obligations to attain specific results, will guarantee a better protection regime. The main reason is that these norms and standards will be easier to enforce, both by the European Commission, the Member States, individuals and NGOs. We can see this better protection in EC court cases, where environmental quality standards are regarded as obligations of result, which individuals can rely upon. ${ }^{25}$ At this moment in time the use of pol-

\footnotetext{
${ }^{23}$ See Krämer [13].

${ }^{24}$ Uitenboogaart/Van Kempen/Wiering/Van Rijswick [26].

${ }^{25}$ Case C-237/07 Janecek [2008] ECR I-6221.
} 
icy discretion should stay within certain boundaries, which means that in the end the use of policy discretion should not harm the achievement of the ultimate goals of a directive.

Exemptions in a directive lead to the conclusion that the corresponding obligation is an obligation of result. ${ }^{26}$ Otherwise the exemptions would not be necessary. Exemptions excuse Member States for not attaining specific results, not for not taking the right measures. Just because of the high number of exemptions in the new water directives, it could be stated that although there is a great deal of policy discretion regarding goal setting for the ecological status, the qualification of water bodies, and the mix of measures that can be taken, at the end of the day the goals and objectives must be achieved, unless there is a justified use of the exemptions. Otherwise it will be very difficult for other Member States in the river basin (for chemical status, for example, downstream Member States, for ecological status also upstream Member States) to achieve a good status in their national waters. An approach solely based on proceduralisation will lead to an unbalanced distribution of measures that have to be taken in the several Member States and it will result in an increased reliance on exemptions.

However, our conclusion at this point is that we should combine both approaches and not leave behind the valuable aspects of the older water directives with their clear goals and standards and to use the new governance insights to improve water management in the future. The latter seems very suitable for new problems we have to solve like the effects of climate change on flood protection and water scarcity and the restoration of the ecology of water systems. A minimum level of protection should, however, be strictly protected in our point of view.

\subsection{The river basin approach: individual obligations versus shared responsibility}

Another new element in water management is the river basin approach. The implementation of the new water directives and the achievement of the objectives of both directives are obligations for the Member States individually, for directives are binding as to the results to be achieved by each Member State. ${ }^{27}$ River basins, though, often cross national or even Community borders. The river basin approach leads to shared responsibilities between Member States within a river basin. This implies that, as to achieving the results individually, the role of transnational cooperation becomes more important in the whole implementation process, including goal setting, the use of exemptions, planning and, last but not least, the taking of practical measures. The Common Implementation Strategy of the Water Framework Directive helps the Member States to use common concepts by implementing the Directive. Cooperation is necessary on the international, the EC, the Member State and the regional level. This

\footnotetext{
${ }^{26}$ At least the existence of limitative exemptions is one of the reasons for the Court of Justice to conclude that the corresponding obligation is an obligation of results. See, for instance, Case C-337/89 Commission/United Kingdom [1992] ECR I-6103; Case C-56/90 Commission/United Kingdom [1993] ECR I-4109; Case C-92/96 Commission/Spain [1998] ECR I-505; Case C-198/97 Commission/Germany [1999] ECR I-3257; Case C-307/98 Commission/Belgium [2000] ECR I-3933; Case C-316/00 Commission/Ireland [2002] ECR I-10527; and Case C-272/01 Commission/Portugal [2004] ECR I-6767.

${ }^{27}$ Article 249 EC Treaty.
} 
will lead to closer cooperation in the future between Member States and the Commission, Member States and non-Member States, between the authorities in different policy fields, between several governmental authorities at the European, state and regional level and, finally, between governmental authorities, non-governmental organizations, stakeholders and the public.

The WFD and the Floods Directive ${ }^{28}$ require that a river basin covering the territory of more than one Member State must be assigned to an international river basin district. Moreover, Member States shall together ensure that the requirements of the WFD for the achievement of the environmental objectives and in particular all programmes of measures are coordinated for the whole of the international river basin district. For this coordination they may use existing structures stemming from international agreements, but this provision does not prohibit Member States from also establishing new structures or concluding new agreements. ${ }^{29}$ In the case of international river basin districts, Member States shall also ensure coordination with the aim of producing single international river basin management plans and international flood risk management plans. ${ }^{30}$

European water directives apparently contain obligations for Member States to cooperate, but they do not prescribe any instruments to shape this cooperation; they only suggest the use of existing structures stemming from international agreements. ${ }^{31} \mathrm{Nei}-$ ther do these directives contain any obligations to execute the programmes of measures collectively, or provisions to collectively hold Member States responsible for the achievement of the results in an international river basin district. Nor do they provide for exemptions if Member States do not attain the required results because of certain acts or omissions by another (Member) State. Issues which cannot be dealt with at Member State level, however, may be reported to the Commission. ${ }^{32}$ However, the absence of cooperation (or poor cooperation) is not a good reason for an individual Member State not to meet its obligations. ${ }^{33}$ Neither the WFD nor the Floods Directive contains any exemptions for Member States not to achieve the prescribed results due to unsuccessful cooperation. As to the 'good chemical status' of surface water, the Directive on Priority Substances ${ }^{34}$ does contain such an exemption in the case of upstream pollution from abroad, as does the Marine Strategy Framework Directive. ${ }^{35}$ Member States can rely on these exemptions in the case of upstream pollution. Having said that, however, relying on such an exemption would be very detrimental to the

\footnotetext{
${ }^{28}$ For the purpose of the Floods Directive Member States shall make use of the arrangements made under Article 3 WFD.

${ }^{29}$ Article 3.4 WFD.

${ }^{30}$ Article 13.2 WFD and Article 8.2 Floods Directive.

${ }^{31}$ See $A c W / C A W$ [2], also see $A c W / C A W$ [1], p. 23.

32 Article 12.1 WFD.

${ }^{33}$ Case C-58/89 Commission/Germany [1989] ECR I-2849.

${ }^{34}$ Directive 2008/105/EC of European Parliament and Council on environmental quality standards in the field of water policy, amending and subsequently repealing Council Directives 82/176/EEC, 83/513/EEC, 84/156/EEC, 84/419/EEC, 86/280/EEC and amending Directive 2000/60/EC, OJ L348/84.

${ }^{35}$ Directive 2008/56/EC of the European Parliament and of the Council of 17 June 2008 establishing a framework for Community action in the field of marine environmental policy, OJ L164/19.
} 
Table 1

\begin{tabular}{|c|c|c|c|}
\hline & $\begin{array}{l}\text { Transposition of general } \\
\text { environmental goal }\end{array}$ & $\begin{array}{l}\text { Legal qualification of general } \\
\text { environmental goal }\end{array}$ & $\begin{array}{l}\text { Legal qualification of specific } \\
\text { goals }\end{array}$ \\
\hline NL & Order in Council (in 2009) & Obligation of best effort & Target values \\
\hline DE & $\begin{array}{l}\text { On the federal (without deadline) } \\
\text { and Länder level }\end{array}$ & Obligation of result & $\begin{array}{l}\text { Intervention values (ecology } \\
\text { still unclear) }\end{array}$ \\
\hline FR & Law & Obligation of result & Probably intervention values \\
\hline $\mathrm{E} \& W$ & No transposition & $\begin{array}{l}\text { Art. } 4 \text { WFD is probably } \\
\text { perceived as an obligation of } \\
\text { result }\end{array}$ & Intervention values \\
\hline DK & Law & $?$ & Intervention values \\
\hline
\end{tabular}

purposes of both the WFD and the Floods Directive. Just for that reason, a reticent attitude should be adopted towards relying upon these exemptions.

\subsection{Differences in implementation}

Member States currently cooperate within river basins, but recent research in five subriver basins shows that there are rather great differences in the implementation of the Water Framework Directive. ${ }^{36}$ The following sub-river basin districts were selected: the Dommel, within the Meuse river basin district in the Netherlands; the Wensum within the Anglia and Wensum catchment area in England; the Rur catchment area in the Meuse river basin district within North Rhine- Westphalia in Germany; St. Brieuc within the Loire-Brittany river basin district and its sub-basin the Baie de St Brieuc in France; and the sub-basin Odense Fjord Basin within Jutland and Funen in Denmark. The differences concern the way in which Member States deal with complexities and policy discretion as well as ambitions and the legal meaning of obligations. There are differences in implementation as far as the following aspects are concerned.

With regard to the qualification of the obligations following from the Water Framework Directive it became clear that not all Members States had implemented the general environmental objectives in their national legislation. The legal qualification of the environmental objectives (article 4 WFD) is in all Member States an obligation of result, except for the Netherlands (see Table 1).

There are also great differences regarding the designation of artificial and heavily modified waters. This can be explained by the different physical and geographical conditions in the Member States. Nevertheless, it also became clear that the attitude towards the designation of waters differs. While in Denmark water bodies are only designated if good status cannot be attained, the Netherlands designates most water bodies as heavily modified or artificial based on the current status of the water bodies (see Table 2).

Also the legal meaning of the "no deterioration" principle differs in several Member States. Ongoing discussion on the question whether the principle should be compared with the well known stand-still principle—no deterioration at all—or has a

${ }^{36}$ Uitenboogaart/Van Kempen/Wiering/Van Rijswick [26]. 
Table 2

\begin{tabular}{llll}
\hline Case RBD/Country & HMWB & AWB & Rest (Natural) \\
\hline RBD Meuse (NL in total) & $92 \%(42 \%)$ & $7 \%(53 \%)$ & $1 \%(4 \%)$ \\
RED Anglia $^{58}$ & $54 \%$ & $15 \%$ & $29 \%$ \\
North Rhine-Westphalia & $>60 \%$ together with AWBs & & $<40 \%$ \\
RED Loire-Brittany & $10 \%$ & $1.5 \%$ & $88.5 \%$ \\
Denmark & $10 \%$ together with AWBs & & $90 \%$ \\
\hline
\end{tabular}

Table 3

\begin{tabular}{llllll}
\hline & $\begin{array}{l}\text { Seriousness } \\
\text { of deterioration }\end{array}$ & Spatial scale & Starting date & Time scale & $\begin{array}{l}\text { Compensation } \\
\text { possible? }\end{array}$ \\
\hline NL & Between status classes & Per water body & 2009 & six-year period & Yes \\
DE & Within status class? & Per water body & 2000 & $?$ & $?$ \\
FR & Between status classes & Per water body & 2009 & six-year period & $?$ \\
E\&W & Between status classes & Per water body & $2006 ?$ & $?$ & No \\
DK & Between status classes & Per water body & $2009 / 2012$ & six-year period & In general, no \\
\hline
\end{tabular}

new meaning, to be explained as no deterioration between the several status classes leads to different results. Also differences in the time scale, the staring period and the possibility for compensation between water bodies lead to a lack of harmonization between the Member States (see Table 3).

The integration with other policy fields like spatial planning, nature conservation and agriculture was also part of the research project and it became clear that all Member States had their own method for taking care of the relationship between water quality objectives and decision making in related policy fields. Internal integration within water management on several governmental levels was mostly well organised and regulated, but external integration shows major differences (see Table 4).

It became clear that agriculture was a difficult topic in all Member Sates, as well as their contribution to the pollution concerned and the possibilities and political will to strengthen regulation. Furthermore, most Member States only want to cooperate with the agricultural stakeholders on a voluntary basis. There is a strong relationship between land use and water protection, which do ask for external integration to achieve the goals of the directive.

It was difficult to discover what the actual amount of investment in water management measures will be per Member State and how cost recovery will be organised. That will need further research. It is not yet fully clear (because the river basin management plans and the programmes of measures were not yet definitive at the time the research was done) what the content of the programmes of measures will be. Important for the success of the Water Framework Directive will be the question whether they contain mainly measures that were all ready obligatory because of older water directives like waste water treatment and obligations following from the Nitrates directive, or whether many new, more ecological measures will be taken. 
Table 4

\begin{tabular}{|c|c|c|c|}
\hline & Authorities in general & Water authorities & Non-water authorities \\
\hline NL & No general integration & $\begin{array}{l}\text { Water plans should take quality } \\
\text { norms into account; when } \\
\text { making specific decisions } \\
\text { authorities should take their } \\
\text { own plans into account }\end{array}$ & $\begin{array}{l}\text { Spatial planning: consult with } \\
\text { water authorities and justify } \\
\text { any derogations (watertoets) }\end{array}$ \\
\hline DE & $\begin{array}{l}\text { RBMPs legally binding on all } \\
\text { authorities }\end{array}$ & $\begin{array}{l}\text { Lower authorities are bound by } \\
\text { the instructions of higher } \\
\text { authorities }\end{array}$ & $\begin{array}{l}\text { No general legal instrument to } \\
\text { oblige other authorities to take } \\
\text { RBMPs into account, but } \\
\text { diverse legal instruments that } \\
\text { ascertain at least to a certain } \\
\text { extent policy integration }\end{array}$ \\
\hline FR & No general integration & $\begin{array}{l}\text { All decisions should be } \\
\text { compatible with RBMPs }\end{array}$ & $\begin{array}{l}\text { Spatial plans should be } \\
\text { compatible with RBMPs }\end{array}$ \\
\hline $\mathrm{E} \& W$ & $\begin{array}{l}\text { Consideration given to both } \\
\text { RBMPs and supplementary } \\
\text { plans }\end{array}$ & Covered by general integration & Covered by general integration \\
\hline DK & $\begin{array}{l}\text { Bound by both RBMPs and } \\
\text { PoMs }\end{array}$ & Covered by general integration & Covered by general integration \\
\hline
\end{tabular}

After these general remarks on the new approach in European water management, which leads to a greater need for transnational cooperation we will further focus on the several kinds of cooperation that are available. We start with a summary of the possibilities for cooperation on the international level and then focus on cooperation on the regional transboundary level. We will finally take another look at the previously mentioned three cases and see on what level and with which instruments cooperation is taking place.

\section{Cooperation in water management at the international level}

Member States shall together ensure the coordination of the requirements of the WFD so as to attain the environmental objectives. They may use existing structures stemming from international agreements. There is a long tradition in international cooperation between states concerning the protection and use of transboundary watercourses. An example is the UN Water Courses Convention, containing five principles for transboundary cooperation in water management. ${ }^{37}$ Another convention on surface water which is important for the EU and its Member States is the already mentioned 1992 Helsinki Convention. Conventions have also been concluded concerning the protection and use of separate watercourses, such as large rivers. These kinds of conventions mostly aim to implement the obligations deriving from the Helsinki Convention within the flowing area of a specific watercourse. Generally, the coordination of the implementation of EC water directives also takes place within the framework

\footnotetext{
${ }^{37}$ The 1997 Convention on the Law of the Non-Navigational Uses of International Water Courses; this convention is not yet in force.
} 
of these conventions. Examples of conventions concerning watercourses that are on EU territory are the Rhine Convention, ${ }^{38}$ the Meuse Treaty, ${ }^{39}$ and the Danube River Protection Convention. ${ }^{40}$ Also (bilateral) treaties have been concluded concerning multiple shared watercourses within a border region between two Member States, for example the Albufeira Convention. ${ }^{41}$ These conventions will be briefly discussed below. We will also discuss the difficulties and limits in using convention mechanisms in transboundary interstate cooperation concerning water management.

\subsection{Conventions on the protection and use of watercourses}

\subsubsection{The UN Water Courses Convention}

As stated above, the UN Water Courses Convention lays down five principles of transboundary cooperation, i.e. the principle of equitable and reasonable utilization; the 'no harm' principle; the general principle of cooperation; the principle of sharing data and information; and the principle of protection and conservation of the ecosystems of international water courses. ${ }^{42}$ Although the convention has not yet entered into force, the International Court of Justice (ICJ) does apply some of these principles as they are derived from customary international law. For example, the principle of equitable and reasonable utilization was applied in the case Gabcikovo-Nagymaros Project. ${ }^{43}$ Further, the UN Water Courses Convention creates a possibility for parties to conclude so-called 'water course agreements', containing agreements on the implementation and interpretation of the convention relating to the protection and the use of an international watercourse.

\subsubsection{The Helsinki Convention}

The Helsinki Convention entered into force on 6 October 1996. Alongside a vast number of EU Member States and (non-member) adjacent states, also the European

\footnotetext{
${ }^{38}$ The 1999 Convention on the Protection of the Rhine; for cooperation between Germany, France, Luxembourg, the Netherlands, Switzerland and the European Community.

${ }^{39}$ The 2003 Meuse Treaty; for cooperation between France, Luxembourg, Germany, Belgium and the Netherlands.

${ }^{40}$ The 1994 Convention on Cooperation for the Protection and Sustainable Use of the Danube River; for cooperation between Austria, Bulgaria, Croatia, the Czech Republic, Germany, Hungary, Moldova, Romania, Slovakia, Slovenia, Ukraine, and the European Community.

${ }^{41}$ The 1998 Convention on Co-operation for Portuguese-Spanish River Basin Protection and Sustainable Use.

${ }^{42}$ See Nollkaemper/de Villeneuve [18]; also see Gilissen [6].

${ }^{43}$ ICJ 25 September 1997, Gabcikovo-Nagymaros Project (Hungary v. Slovakia). Applying the principle as customary law, the ICJ stated: "The Court considers that Czechoslovakia, by unilaterally assuming control of a shared resource, and thereby depriving Hungary of its right to an equitable and reasonable share of the natural resources of the Danube - with the continuing effects of the diversion of these waters on the ecology of the riparian area of the Szigetkoz-failed to respect the proportionality which is required by international law."
} 
Community is a party to the convention. An important aspect of the Helsinki Convention is the geographical approach, dividing watercourses into river basins. This river basin approach is also incorporated in the European water directives mentioned.

The Helsinki Convention consists of three parts. The first part contains general provisions which are applicable to all the parties to the convention. Among others, the precautionary principle, the polluter-pays principle, the no-harm principle, the principle of cooperation and the principle of sharing data and information have found their way into the Helsinki Convention, and are applicable to all parties. ${ }^{44}$ The second part contains further rules for riparian states to elaborate their cooperation. For this purpose, the riparian state parties shall, on the basis of equality and reciprocity, conclude bilateral or multilateral agreements or other arrangements. On the basis of these agreements joint bodies or commissions have to be established. Several tasks of these joint bodies are inter alia to collect, compile and evaluate data in order to identify pollution sources which are likely to have a transboundary impact; to elaborate joint monitoring programmes concerning water quality and quantity; to develop concerted action programmes for the reduction of pollution loads from both point sources and diffuse sources; to establish a forum for the exchange of relevant information; and to establish warning and alarm procedures. ${ }^{45}$ Examples of agreements concluded by virtue of the Helsinki Convention are the Rhine Convention, the Meuse Convention and the Danube River Protection Convention. ${ }^{46}$ The third part consists of institutional and final provisions, for example on the convening of a meeting between the parties which shall, under normal conditions, be held every three years.

\subsubsection{Conventions implementing the Helsinki Convention and/or concerning the coordination of the implementation of the WFD}

Over time, many conventions have been concluded (and repeatedly amended) concerning specific transboundary watercourses. These conventions mainly tend to implement the Helsinki Convention, and in a way the UN Water Course Convention. Also the implementation of EC water directives generally takes place within the frameworks of these conventions, although problems may arise, especially when the EC itself or non-Member States are parties to these conventions. These conventions have extensive similarities, but also important differences can be pointed out. As an important similarity, these conventions all establish river protection commissions. The success of these commissions differs, though. Other differences mostly concern the content of the conventions and the parties thereto.

\subsubsection{Rhine Convention}

The 1999 Rhine Convention is probably the best-known example of a treaty on transboundary cooperation between riparian states as it is widely considered to have been

\footnotetext{
${ }^{44}$ These principles also apply to non-riparian states that are parties to the convention, in order to protect water courses from pollution from the land.

${ }^{45}$ Article 9 Helsinki Convention.

${ }^{46}$ These conventions all refer to the Helsinki Convention in their preambles.
} 
successful. ${ }^{47}$ The Rhine Convention has been ratified by Germany, France, Luxembourg and the Netherlands (EU Member States), Switzerland (a non-Member State) and the European Community. The main aims to be pursued by the parties through the Rhine Convention are the sustainable development of the Rhine ecosystem, the production of drinking water from the waters of the Rhine, the improvement of sediment quality, and general flood prevention and protection. ${ }^{48}$ The convention lists a number of principles, mostly derived from the Helsinki Convention ${ }^{49}$ and the UN Water Course Convention, by which the parties shall be guided. The core principle is the parties' obligation to refrain from causing significant transboundary (environmental) damage. This principle is to be elaborated by taking measures preventing, controlling and reducing transboundary water pollution. ${ }^{50}$ By taking these measures, inter alia the precautionary principle, the principle of preventive action, the polluter-pays principle, the principle of not increasing damage, and the principle of sustainable development have to be taken into account. ${ }^{51}$ To achieve the main aims of the convention, the parties have to undertake certain actions, such as the intensification of cooperation and the implementation of international measuring programmes.

To implement the Rhine Convention, the parties pursue their cooperation within the International Commission for the Protection of the Rhine (ICPR). ${ }^{52}$ To achieve the aims of the convention, this commission (having legal personality) shall accomplish certain tasks, such as preparing international measuring programmes and studies of the Rhine ecosystem, making proposals for individual measures and programmes of measures, and evaluating the effectiveness of the actions and the results of the programmes of measures. ${ }^{53}$ Decisions of the ICPR shall be taken unanimously, and shall, in principle, be implemented by the parties in accordance with their national law.

The Rhine Convention and the ICPR are not suitable for coordinating and harmonizing the implementation of the WFD as a non-Member State and the European Community are also parties to the convention. Therefore, an informal committee has been established (the Rhine Coordination Committee). The bilateral informal coordination of the implementation of the WFD also takes place within the Permanent Dutch-German Border Water Commission. ${ }^{54}$

\subsubsection{Meuse Treaty}

The 2002 Meuse Treaty ${ }^{55}$ is another example of a treaty on transboundary cooperation between riparian states. This treaty contains a regulation on cooperation between

\footnotetext{
${ }^{47}$ See Dieperink/Glasbergen [5], pp. 45-49.

${ }^{48}$ Article 3 Rhine Convention.

${ }^{49}$ Paragraph 4 of the preamble refers to the Helsinki Convention.

${ }^{50}$ See Keessen/Van Kempen/Van Rijswick [12], p. 38.

${ }^{51}$ Article 4 Rhine Convention.

${ }^{52}$ For a more thorough focus on (the work of) the ICPR: Peeters [19], pp. 210-215.

${ }^{53}$ Article 8 Rhine Convention.

${ }^{54}$ See Gilissen [6], pp. 52-53.

${ }^{55}$ This treaty was concluded at the same time and place as the 2002 Scheldt Treaty. With respect to their content and objectives, both treaties are very similar.
} 
the parties concerning the entire Meuse river basin. All parties to the Meuse Treaty are EU Member States, namely Belgium, France, Germany, Luxembourg and the Netherlands. The Meuse Treaty is not only meant to implement the Helsinki Convention, but unlike the Rhine Convention it has also been concluded to create a multilateral structure for the execution of the obligations arising from the WFD, as stated in Article 4.3 of the treaty. ${ }^{56}$ The main aim of the Meuse Treaty is the sustainable and integrated water management of the whole international Meuse river basin district, taking into account the multiple goals of the River Meuse. Just as in the Rhine Convention, a number of principles have been laid down in the Meuse Treaty, such as the precautionary principle, the principle of preventive action, and the polluter-pays principle. The Meuse Treaty contains fewer principles than the Rhine Convention.

Also by virtue of the Meuse Treaty an international commission has been established to guide the implementation of this treaty. The main task of the International Meuse Commission (IMC) ${ }^{57}$ is to advise and to recommend the parties, and to encourage their cooperation. Also the multilateral adjustment of the implementation of the WFD by the individual Member States takes place within the IMC. Unfortunately, the IMC has not yet proved as successful as the ICPR, mainly because of the absence of the competence to establish decisive programmes of measures. The IMC also has no competence to bind the parties to its decisions.

Alongside the Dutch-Belgian border, also informal bilateral cooperation and the coordination of the WFD takes place within the Walloon-Dutch Water Consultation, and within the Dutch-Flemish Integral Water Consultation.

\subsubsection{Danube River Protection Convention}

The last multilateral convention to be discussed here is the Danube River Protection Convention. The parties to this convention are Austria, Bulgaria, Croatia, the Czech Republic, Germany, Hungary, Moldova, Romania, Slovakia, Slovenia, Ukraine, and the European Community. Except for Croatia, Moldova and the Ukraine these are all EU Member States. The main objectives of the convention are to achieve the goals of sustainable and equitable water management, including the conservation, improvement and rational use of surface waters and groundwater in the international Danube river basin district. To achieve these objectives, the parties shall cooperate on fundamental water management issues, and they shall take all appropriate measures to maintain and improve current environmental and water quality conditions. For all measures aiming at the protection of the Danube river basin the precautionary principle and the polluter-pays principle constitute a basis.

Regarding the implementation of the objectives and provisions of the convention, the International Commission for the Protection of the Danube River (ICPDR) has been established. For implementing the obligations arising from the convention, the ICPDR elaborates proposals and recommendations for the parties. The ICPDR also carries out projects, specifying measures to be taken to achieve the objectives of the

\footnotetext{
${ }^{56}$ Also see $C A W[3]$.

${ }^{57}$ For a more thorough focus on (the work of) the IMC: Peeters [19], pp. 203-210.
} 
convention (e.g. the Joint Action Programme). The coordination of the implementation of the WFD takes place on the basis of a multilevel coordination mechanism for coordination at regional, national, bilateral and multilateral and Danube river basin level. The ICPDR has responsibility for coordinating the cooperation and implementing the WFD at the Danube river basin level.

\subsubsection{Albufeira Convention}

After having concluded separate regional treaties since the $18^{\text {th }}$ century, in 1998 Portugal and Spain concluded the Albufeira Convention containing a framework for bilateral cooperation in the integrated management of the Minho, Lima, Duoro, Tejo and Guadiana river basins. This Convention entered into force in January 2000. Although, by then, the WFD was still in the development stage, the Albufeira Convention was framed in accordance with the WFD, incorporating inter alia the river basin approach. ${ }^{58}$ It also incorporates principles derived from the UN Water Courses Convention and the Helsinki Convention, namely the principle of equitable and reasonable utilization and the no-harm principle. ${ }^{59}$ The main aim of the Albufeira Convention is to conduct the sustainable development of all the shared river basins by defining a framework for bilateral cooperation.

The convention provides for two main institutions, namely the Conference of the Parties to the Albufeira Convention (COP) and the Commission on the Application and Development of the Convention (CADC). The COP regulates the cooperation between Portugal and Spain at a high political level, and therefore mainly has a political role. The COP only meets when necessary to reach consensus on transboundary water issues between both parties to the convention. ${ }^{60}$ The CADC, which has been especially successful since 2005 , is the convention's operational body, meeting at least once a year ${ }^{61}$, and from 2006 onwards consisting of four Working Groups ${ }^{62}$ and one Sub-commission on public participation. A Spanish and a Portuguese delegation, consisting of members ${ }^{63}$ designated by each country's central government, compose the Commission. The CADC (through its fourth Working Group) is responsible for coordinating the implementation of the WFD. Further, a proposal to establish a Permanent Technical Secretariat was accepted by the COP at its second meeting in February 2008. The aim is that this secretariat will start to function in 2009. Its main function is to define methods to elaborate the river basin management plans of the shared river basin districts. ${ }^{64}$

\footnotetext{
${ }^{58}$ See Maia [16].

${ }^{59}$ See Costa/Vergés/Barraqué [4].

${ }^{60}$ The COP has met only twice, first in July 2005 to discuss the need for increasing cooperation mechanisms concerning droughts and the implementation of the WFD. The second occasion was in February 2008 to establish a new (seasonal) flow regime guaranteeing minimal flows, and to approve statutory rules of the CADC. Also see Maia [16], p. 3.

${ }^{61}$ From 2005 onwards the CACD has actually met twice a year.

${ }^{62}$ One on a flow regime, droughts and emergency situations; one on information exchange; one on the safety of aquatic infrastructure and floods; and one on WFD issues and water quality.

${ }^{63}$ Both delegations consist of an equal number of members, with a maximum of nine.

${ }^{64}$ See Maia [16], p. 4.
} 


\subsection{Difficulties of and limitations to cooperation at the international level}

As seen above, international cooperation between states in water management often takes place by virtue of multilateral conventions. These conventions regulate the cooperation between states by stipulating obligations for the parties, by determining principles to be taken into account in transboundary cooperation, and by establishing commissions to provide guidance in coordinating the implementation of the conventions. But there are some difficulties and limitations to the use of multilateral conventions.

First, these conventions are suitable for cooperation on the international level concerning large rivers or large border areas. This is an important limitation to the use of this instrument, mainly in achieving the objectives (environmental standards) of the EC water directives. To meet these objectives in practice, the involvement of regional water authorities in taking concrete measures is also required. These authorities cannot cooperate on the basis of watercourse conventions. Cooperation between these sub-national authorities concerning regional (smaller) water courses within a single river basin is of importance as these smaller water courses occasionally also cross borders, and often run into larger rivers affecting their water quality and quantity. So, one should bear in mind that multilateral convention mechanisms are unsuitable for transboundary cooperation between regional authorities, concerning smaller water courses or specific border regions. Because watercourse conventions have their limitations, we argue that these conventions are not the only instruments which should be focused upon while giving shape to transboundary cooperation in water management. Here again, we emphasize the importance of transboundary cooperation between regional water management authorities, alongside the international cooperation at a high political level.

Second, the mentioned watercourse conventions are sometimes less suitable as instruments for the implementation of obligations arising from European law. This is especially problematic in the case of so-called mixed treaties, to which non-Member States and the European Community are parties alongside EU Member States. These conventions, such as the Helsinki Convention, mostly serve several purposes and do not have the implementation of European law as one of their objectives. ${ }^{65}$ Keessen et al. state that treaties concluded with respect to specific rivers would be more appropriate for the implementation of obligations regarding cooperation arising from European water directives. ${ }^{66}$ That might be true when only Member States are parties to the convention (for example, in the case of the Meuse Treaty), but this might still be problematic when non-Member States and/or the European Community are parties to the convention (for example, the Rhine Convention and the Danube River Protection Convention). As we have seen, cooperation (i.e. the coordination of the implementation) in the latter case mostly takes place on an informal basis, if need be within the framework of the relevant convention and/or coordinated by a commission or committee.

\footnotetext{
${ }^{65}$ See Hey/Van Rijswick [10].

${ }^{66}$ See Keessen/Van Kempen/Van Rijswick [12], p. 38.
} 


\section{Cooperation in water management at the regional transboundary level}

As stated above, the international level is not the only level on which transboundary cooperation in water management should take place. In achieving the purposes of the European water directives, also at the regional level transboundary cooperation is required, not only because a substantial part of the water in large rivers comes from smaller (transboundary) watercourses, but also because these smaller water courses are themselves part of the river basins. In accordance with the Preamble to the WFD the success of the directive relies on close cooperation and coherent action at Community, Member State and regional levels. ${ }^{67}$ Recently, the conscious need for transboundary cooperation in water management, especially at the regional level, has impressively increased. For example, in the Netherlands the year 2009 has been proclaimed as 'the year of transboundary cooperation in water management'. Multilateral convention instruments, as described above, are less suitable for transboundary cooperation between regional water authorities. This emphasizes the need for other cooperation mechanisms.

In this section we discuss the cooperation concerning water management at the regional level. We will first make some general remarks on the cooperation at this level. Thereafter, we will describe several instruments for regional transboundary cooperation, which could be used by water managers. To give examples of the possibilities, we will focus on several instruments for cooperation between Dutch water managers and their Flemish/Walloon and German counterparts in border regions. The general aspects of these forms of cooperation (mostly based on the 1980 Madrid Convention) could be mutatis mutandis applicable to other border regions. An instrument to which we devote special attention is the European Grouping on Territorial Cooperation based on the recently adopted EGTC Regulation.

\subsection{General remarks on regional transboundary cooperation}

Cooperation and transboundary contacts between decentralized government bodies are not a typically $21^{\text {st }}$ century matter. In fact, these bodies have been cooperating since national borders were first demarcated and they have played an important role in the development of transboundary cooperation structures. Especially shortly after the Second World War prominent persons from border regions contacted each other, at first leading to informal cooperation, but later to more intense and formal forms of cooperation. One of the first structural forms of transboundary cooperation in Europe was the EUREGIO (in the Dutch-German border region). This form of cooperation has been an example to many transboundary contacts across Europe, later being called Euregions (after this first and successful cooperation structure). At the beginning, Euregions were informal organizations with a slightly idealistic initial concept, but as the conscious need for transboundary cooperation grew, these organizations became more formalized, and most were granted a private legal status. After concluding the 1980 Madrid Convention ${ }^{68}$ and bilateral or trilateral conventions based

\footnotetext{
${ }^{67}$ Paragraph 14 Preamble WFD.

${ }^{68}$ European Outline Convention on Transfrontier Co-operation between Territorial Communities or Authorities, signed in Madrid on 21 May 1980.
} 
on the Madrid Convention were also concluded, the Euregions could even be given a public legal status, and some Euregions made use of this possibility. ${ }^{69}$

The 1980 Madrid Convention obliges the parties to make their best efforts to establish further agreements concerning transboundary cooperation between territorial (i.e. decentralized) communities or authorities. ${ }^{70}$ For example, both the Benelux Agreement (BA) and the Anholt Agreement (AA) derive from the Madrid Convention. By virtue of the BA, Dutch, Flemish, Walloon and Luxembourg decentralized authorities can form transboundary cooperation structures (see below). By virtue of the AA, Dutch and German authorities can do the same, but Dutch district water boards do not fall under the scope of this agreement. Therefore, we will not pay any further attention to this agreement below. ${ }^{71}$ Dutch and German water managers can cooperate on the basis of the Dutch-German Border Convention, which will be discussed below.

There is at least one complicating factor in transboundary cooperation between EU Member States water management authorities at the regional level. On the basis of the WFD, Member States shall ensure that a river basin covering the territory of more than one Member State is assigned to an international river basin district. In that case each Member State shall individually ensure the appropriate administrative arrangements, including the identification of the appropriate competent authority, for applying the rules of the directives within the portion of any international river basin district within its territory. ${ }^{72}$ The WFD does not contain any further rules on the indication of appropriate competent authorities. Therefore, Member States have a great deal of discretion when indicating such authorities, which has led to very diverse administrative arrangements and a highly incompatible division of competences between administrative bodies in border regions across Europe. For example, Dutch water management competences are allocated to the central government and to district water boards at the regional level. ${ }^{73}$ German water management competences are to be found at the federal level, as well as at the so-called Wasserbehörde of general governmental bodies at the Land, regional and local levels. ${ }^{74}$ In Belgium water management competences are mostly divided between the 'gewesten' (regions or districts), the provinces and the municipalities. ${ }^{75}$ These differences in the division of competences-not only in the Dutch border region-are a complicating factor in transboundary cooperation at the regional level, alongside possible cultural and linguistic differences.

\footnotetext{
${ }^{69}$ For the development of Euregions over time see Uijen [25].

${ }^{70}$ For a further analysis of the Madrid Convention see Hertoghs/Hoetjes [9].

${ }^{71}$ We think that Dutch district water boards should be able to cooperate by virtue of the Anholt Agreement, mainly because water policy is nowadays becoming more integrated in (general) environmental policy. The fact that in the Netherlands regional water management is (mainly) a task for functionally decentralized authorities provides no reason to exclude these authorities from cooperating by virtue of general cooperation mechanisms such as the Anholt Agreement. Dutch district water boards are also not excluded from cooperating by virtue of the Benelux Agreement.

${ }^{72}$ Article 3.3 WFD.

${ }^{73}$ See Reinhard/Folmer [20].

${ }^{74}$ More comprehensively Solf [24].

${ }^{75}$ See Maes/Lavrysen [15].
} 


\subsection{Regional transboundary cooperation between Dutch and German water managers}

In 1960 the Dutch-German Border Convention was concluded. Concerning transboundary water management, Chap. 4 of this convention is of importance. As stated above, in 1963 the Permanent Dutch-German Border Water Commission (PBWC) was established to-for the benefit of cooperation in good neighbourliness-shape an interstate consultation and cooperation framework for water-related issues with respect to border waters. ${ }^{76}$ The PBWC only consists of State government representatives; no delegates from decentralized authorities have a seat in this commission. Seven sub-commissions assist the PBWC. Each transboundary river basin is represented by a sub-commission, in which also delegates of the competent regional water management authorities on both sides of the border are represented. These sub-commissions have the same tasks and competences as the PBWC, except for receiving and dealing with notices of objection.

These competent water management authorities (just as the central governments) also have the possibility to conclude so-called special agreements with their foreign counterparts concerning the distinctive border waters under their regime. ${ }^{77}$ It remains unclear whether these agreements have the status of public international law agreements or agreements under national (private or public) law. ${ }^{78}$ We think that these agreements have a national law character as no state actors are (directly) party to them. It depends on the merits of the agreement whether the agreements are of a private or public law nature. Agreements only containing settlements on the maintenance of border waters (or the defrayment thereof) will be of a private law nature (maintenance agreements). Agreements concluding settlements on the exercise of administrative competences can be seen as of a public law nature (competence agreements). In practice, only agreements of the first type have been concluded. Furthermore, it seems that after 1994 no use has been made of the possibility to conclude special agreements.

It also has to be mentioned that the PBWC and the sub-commissions functioned quite well until the entry into force of the WFD. Thereafter, the PBWC and the subcommissions no longer seem to function that well. A reason for this could be an organizational disagreement between the Netherlands and Germany on the use of these networks for coordinating the implementation of the WFD. ${ }^{79}$ From 2002 onwards, the transboundary coordination of river basin management plans has (quite successfully) taken place within the so-called Steuerungsgruppe and several working groups. The aim is to intensify and eventually formalize this form of cooperation. Within this formal framework (to be), more structural regional transboundary cooperation could be given shape. It is still uncertain which construction of transboundary

\footnotetext{
${ }^{76}$ Articles 57 jo. 64 Border Convention.

${ }^{77}$ Article 59.2 Border Convention.

${ }^{78}$ See Heemskerk [7], pp. 182-183; also see Seerden [22], p. 224.

${ }^{79}$ The Netherlands wanted the tasks of the PBWC network to be enhanced with the competence to deal with transboundary WFD issues. Germany did not agree to that. See $A c W / C A W[1]$, p. 10.
} 
cooperation is to be chosen. We think that the Anholt Agreement is as a possibility (only if the Dutch regional water boards can be brought under the scope of that agreement). Another option is cooperation under the EGTC Regulation. We expect that both possibilities will eventually lead to the annulment of the old cooperation mechanism under the Dutch-German Border Convention.

\subsection{Regional transboundary cooperation between Dutch and Belgian water managers}

As mentioned above, the 1980 Madrid Convention encouraged its parties to enter into further agreements concerning transboundary cooperation between territorial communities or authorities. With regard to this convention, in 1986 the Netherlands, Belgium and Luxembourg concluded the trilateral Benelux Agreement on transboundary cooperation between territorial communities and authorities (BA) ${ }^{80}$ For this section, we focus on the cooperation between Dutch and Flemish (water management) authorities under the BA. Where comparable (bilateral or trilateral) agreements have been concluded elsewhere in Europe, the text below is mutatis mutandis applicable, unless regulated otherwise, of course.

The BA provides a default system for Dutch and Flemish authorities to establish transboundary cooperation structures. The authorities which are competent to establish these structures are Dutch provinces, municipalities, district water boards and joint public bodies, and Flemish provinces, municipalities, so-called polders and wateringen (polders and watercourses), associations of municipalities and public centres for social well-being. In the Netherlands it is mainly the district water boards that have been given competences concerning water management. In Flanders water management competences are to be found at different administrative levels (mainly provinces, municipalities, and polders and watercourses). So, to establish a wellfunctioning structure for transboundary cooperation all these authorities have to be involved.

The BA provides for the establishment of three different transboundary cooperation structures, namely the administrative settlement, the common organ, or the transboundary public body. Cooperating authorities can freely chose between these structures. The administrative settlement is often regarded as the most effortless form of cooperation under the BA. This could be proven wrong as the administrative settlement indeed does not intend to establish an umbrella organ or body, but can definitely impose legally enforceable obligations on the parties. Administrative settlements generally contain agreements on the reciprocal exercise of certain administrative competences, such as licensing competences. Therefore, the administrative settlements are to be seen as competence agreements under national public law. It also seems possible to conclude agreements on the (defrayment of) maintenance of border waters. This kind of administrative settlement is a maintenance agreement under national private law.

\footnotetext{
${ }^{80}$ Trb. 1986, 160; in force on 1 April 1991. Recently on the possibilities for water managers to cooperate under the BA: Gilissen [6], pp. 76-84.
} 
Another form of cooperation based on the BA is the establishment of a common organ. A common organ is to be seen as a formal consultation structure without any legal personality. There is some uncertainty concerning to what extent autonomous competences can be assigned to a common organ, ${ }^{81}$ but certainly no competences can be assigned by which a common organ can make decisions which are legally binding for citizens, such as decisions concerning the assessment of taxes or the establishment of ordinances. ${ }^{82}$ The cooperating authorities, if they so wish, can assign competences to a common organ by which it can make decisions which are legally binding on them. ${ }^{83}$ Above all, the establishment of a common organ provides for the founding of a consultation forum without legal personality, on the basis of which cooperating authorities can meet to intensify their contacts and cooperation. ${ }^{84}$

The last and most thorough form of transboundary cooperation is the establishment of an autonomous public body. A public body has full legal personality, and the cooperating authorities can choose to assign administrative and regulative competences to it. If so, the public body is competent to make decisions which are legally binding for citizens. ${ }^{85}$ Legal relationships between the public body and their legal subordinates (natural or legal personalities) are regulated by the national law of the state (Dutch or Belgian law) on whose territory the public body exercises its competences. The legal relationship between the public body and its employees, in principle, is regulated by the national law of the state where the public body has its registered office.

The BA provides a good framework to establish formal transboundary cooperation structures between Dutch and Flemish water management authorities. In practice, nevertheless, no cooperation structures have yet been established by water managers on the basis of the BA. Cooperation structures have been established between Dutch and Flemish provinces and between Dutch and Flemish municipalities, but the Dutch district water boards do not seem to be involved in this kind of formal cooperation. A reason for this might be that water management competences in Flanders have mostly been assigned to general public authorities (provinces and municipalities), whereas the Dutch water management competences have been assigned to the functionally decentralized water boards, which have no direct counterpart across the border. Dutch district water boards generally express the desire to formalize cooperation with Flemish water management authorities, especially because informal regional cooperation structures (such as the transboundary river basin committees under the umbrella of the Dutch-Flanders Integral Water Consultation) do not work successfully. ${ }^{86}$

\footnotetext{
${ }^{81}$ Mostly because the BA does not contain an elaboration of this cooperation structure.

${ }^{82}$ See Seerden [22], p. 155.

${ }^{83}$ Ministerie van Binnenlandse Zaken [17], p. 18.

${ }^{84}$ See Hertoghs [8], p. 112.

${ }^{85}$ See Seerden [23], p. 128.

${ }^{86}$ See Gilissen [6], p. 85.
} 
5.4 Regional transboundary cooperation between water managers on the basis of the EGTC Regulation

In this article, special attention is paid to the Regulation on a European Grouping of Territorial Cooperation (EGTC Regulation) ${ }^{87}$ as this regulation provides not only for a new form of transboundary cooperation, but it is, in contrast with for example the Border Convention and the BA, also generally applicable in European border regions. ${ }^{88}$ The preamble to the regulation states that measures are necessary to reduce the significant difficulties encountered by Member States and, in particular, by regional and local authorities in implementing and managing actions of territorial cooperation within the framework of differing national laws and procedures. ${ }^{89}$ In order to overcome these difficulties, it is necessary to institute a cooperation instrument at Community level for the optional creation of cooperative groupings with legal personality and extensive legal capacity. ${ }^{90}$ For this objective, the regulation provides for the establishment of an EGTC by Member States, regional authorities, local authorities and/or other bodies governed by public law ${ }^{91}$ for the purpose of facilitating and promoting cross-border, transnational and/or interregional cooperation (i.e. territorial cooperation), with the exclusive aim of strengthening economic and social cohesion. ${ }^{92}$ The possibility to establish an EGTC is additional to the opportunities and frameworks provided by the acquis of the Council of Europe ${ }^{93}$, within which regional and local authorities can cooperate across borders. The EGTC instrument is explicitly not intended to circumvent those frameworks or to provide a set of common rules, which would uniformly govern all such arrangements throughout the Community. ${ }^{94}$ An EGTC should, therefore, be able to act, either for the purpose of implementing territorial cooperation programmes or projects co-financed by the Community, or for the purpose of carrying out actions of territorial cooperation initiated by the Member States and/or their regional and local authorities, ${ }^{95}$ although an EGTC could never obtain competences exercised by regional and local authorities as public bodies, such as policing and regulatory competences. ${ }^{96}$

\footnotetext{
${ }^{87}$ Regulation No. 1082/2006 of the European Parliament and of the Council of 5 July 2006 on a European grouping of territorial cooperation (EGTC), OJ L 210/19. This regulation entered into force on 1 August 2007.

${ }^{88}$ Recently on the possibilities for water managers to cooperate under the EGTC Regulation: Gilissen [6].

${ }^{89}$ Paragraph 2 Preamble EGTC Regulation.

${ }^{90}$ Paragraphs 8 and 9 Preamble EGTC Regulation.

${ }^{91}$ Where the legislation of a third country or agreements between Member States and third countries so allow, the EGTC Regulation does not exclude the possibility of entities from third countries participating in an EGTC (Paragraph 16 Preamble EGTC Regulation). An EGTC, though, should always be made up of members located on the territory of at least two Member States (Article 3.2 EGTC Regulation).

${ }^{92}$ Articles 1.2 and 3.1 EGTC Regulation.

${ }^{93}$ Mainly the 1980 Madrid Convention and the bilateral or trilateral agreements based on that convention are meant here.

${ }^{94}$ Paragraph 5 Preamble EGTC Regulation.

${ }^{95}$ Paragraph 11 Preamble EGTC Regulation.

${ }^{96}$ Paragraph 13 Preamble EGTC Regulation.
} 
Table 5

\begin{tabular}{|c|c|c|c|c|}
\hline $\begin{array}{l}\text { Form of } \\
\text { cooperation }\end{array}$ & Parties & $\begin{array}{l}\text { Objectives/subject of } \\
\text { cooperation }\end{array}$ & $\begin{array}{l}\text { Legal } \\
\text { personality }\end{array}$ & Competences \\
\hline $\begin{array}{l}\text { Special } \\
\text { agreement } \\
\text { (Border } \\
\text { Convention) }\end{array}$ & $\begin{array}{l}\text { Dutch/German } \\
\text { regional water } \\
\text { management } \\
\text { authorities }\end{array}$ & $\begin{array}{l}\text { Mainly maintenance } \\
\text { agreements (private law); } \\
\text { possibly agreements on } \\
\text { exercising competences } \\
\text { (public law) }\end{array}$ & - & $\begin{array}{l}\text { No transfer of competences; } \\
\text { agreements on the exercise of } \\
\text { competences }\end{array}$ \\
\hline $\begin{array}{l}\text { Administrative } \\
\text { Settlement } \\
\text { (Benelux } \\
\text { Agreement) }\end{array}$ & $\begin{array}{l}\text { Dutch/Belgian } \\
\text { regional } \\
\text { authorities and } \\
\text { local, } \\
\text { including } \\
\text { water } \\
\text { management } \\
\text { authorities }\end{array}$ & $\begin{array}{l}\text { Mainly agreements on } \\
\text { exercising competences } \\
\text { (public law) }\end{array}$ & - & $\begin{array}{l}\text { No transfer of competences; } \\
\text { agreements on the exercise of } \\
\text { competences }\end{array}$ \\
\hline $\begin{array}{l}\text { Common } \\
\text { Organ } \\
\text { (Benelux } \\
\text { Agreement) }\end{array}$ & As above & $\begin{array}{l}\text { Mainly a consultation forum } \\
\text { for parties; discussing } \\
\text { transboundary water issues }\end{array}$ & No & $\begin{array}{l}\text { No autonomous public } \\
\text { competences; decisions can } \\
\text { legally bind parties }\end{array}$ \\
\hline $\begin{array}{l}\text { Transboundary } \\
\text { Public Body } \\
\text { (Benelux } \\
\text { Agreement) }\end{array}$ & As above & $\begin{array}{l}\text { Cooperation through an } \\
\text { autonomous body with legal } \\
\text { personality and capacity; } \\
\text { "transboundary water } \\
\text { management authority" }\end{array}$ & Yes & $\begin{array}{l}\text { Autonomous administrative } \\
\text { and regulatory competences } \\
\text { (if parties so wish) }\end{array}$ \\
\hline EGTC & $\begin{array}{l}\text { Member } \\
\text { States, } \\
\text { regional and } \\
\text { local } \\
\text { authorities }\end{array}$ & $\begin{array}{l}\text { Joint determination and } \\
\text { implementation of (water) } \\
\text { policy; joint execution of } \\
\text { operational tasks }\end{array}$ & Yes & $\begin{array}{l}\text { No autonomous public } \\
\text { competences; most extensive } \\
\text { legal capacity to acts of } \\
\text { private law }\end{array}$ \\
\hline
\end{tabular}

When we compare the several instruments for regional transboundary cooperation, given their possibilities for parties to regulate the subject of cooperation, the possibility to create an organization with legal personality and the competences that can be given within the several forms of cooperation, we can provide the following overview (see Table 5).

This overview shows the attractive possibilities of the EGTC. Member States as well as regional and local authorities can be members of an EGTC. Therefore, also (public) water management authorities can be members of such a cooperation structure. An EGTC has, in order to fulfill its tasks, legal personality and in each Member State the most extensive legal capacity accorded to legal persons under that state's national law. In particular, it may acquire or dispose of movable and immovable property and employ staff, and may be a party to legal proceedings. ${ }^{97}$ An EGTC at least consists of an assembly, which is made up of representatives of its members, and of a director, who represents the EGTC and acts on its behalf. The statutes may provide for additional organs with clearly defined competences. ${ }^{98}$ These organs can

\footnotetext{
${ }^{97}$ Articles 1.3 and 1.4 EGTC Regulation.

${ }^{98}$ Article 10 EGTC Regulation.
} 
have general competences concerning the EGTC, but they can also have more specific competences, for example concerning water or spatial planning issues. ${ }^{99}$

The establishment of an EGTC is optional for the authorities wishing to cooperate. The decision to establish an EGTC takes place at the initiative of its prospective members, which will each notify the Member State under whose law it has been formed of its intentions to participate in the EGTC. They also have to send that Member State a copy of the proposed convention and statutes by which the EGTC shall be governed. Thereafter, the Member State concerned shall, in principle, ${ }^{100}$ approve the prospective member's participation in the EGTC within three months. ${ }^{101}$

After approval by the Member State concerned, the members of the EGTC shall unanimously agree on the convention and the statutes, ensuring consistency with the approval. The EGTC itself is governed by this convention, on the basis of which the statutes for internal regulation (such as decision-making procedures, the working language, functioning arrangements, et cetera) shall be adopted. ${ }^{102}$ The convention inter alia specifies the name of the EGTC, a list of the EGTC's members, the extent of the territory on which it may execute its tasks, and the law applicable to the interpretation and enforcement of the convention (which is the law of the Member State where the EGTC has its registered office). It also specifies the specific objectives and tasks of the EGTC. These objectives and tasks could be of a general nature, but an EGTC could also have a more specific composition of objectives and tasks, for example concerning transboundary cooperation within the policy field of water management.

As to the objectives and tasks specified by the convention, the following can be said. An EGTC shall carry out the tasks given to it by its members in accordance with the regulation. The members can only assign tasks to an EGTC which fall within their competences under national law. The EGTC shall act within the confines of the tasks given to it, which shall be limited to the facilitation and promotion of territorial cooperation to strengthen economic and social cohesion. Specifically, these tasks shall be limited primarily to the implementation of territorial cooperation programmes or projects co-financed by the Community through specific European funding mechanisms, but an EGTC may also carry out other specific actions of territorial cooperation by its members. It is most important that the tasks given to an EGTC shall not concern the exercise of competences conferred by public law or of duties whose object is to safeguard the general interest of states or of other public authorities, such as policing or regulatory competences, justice and foreign policy. ${ }^{103}$ The exercise of public competences explicitly remains a task for the members of the EGTC. The EGTC, therefore, is a suitable cooperation structure to determine joint (or coordi-

\footnotetext{
${ }^{99}$ See Gilissen [6], pp. 94-96.

${ }^{100}$ The Member State concerned shall approve the participation, unless it considers that such participation is not in conformity with the EGTC Regulation or national law, including the prospective member's competences and duties, or that such participation is not justified for reasons of public interest or of the public policy of that Member State.

${ }^{101}$ Article 4 EGTC Regulation.

${ }^{102}$ Articles 8 and 9 EGTC Regulation.

${ }^{103}$ Article 7 EGTC Regulation.
} 
nated) policy on certain issues (such as water management) and to jointly implement this policy by way of executing operational tasks together. ${ }^{104}$

In accordance with the above, and to fulfill its task properly, an EGTC has legal personality and the most extensive legal capacity accorded to legal persons under the national law of the Member State where it exercises its competences. This legal personality and legal capacity in particular concern (private) law acts, such as acquiring or disposing of movable or immovable property, employing staff, or being a party to legal proceedings.

In practice, no EGTCs have yet been established by EU Member State water management authorities. That may be because the instrument is relatively in its infancy and unknown, but also because water managers may think that this form of cooperation is too intense and too formal. For example, the Dutch district water board De Dommel expressed its wish to cooperate with its Flemish counterparts on the basis of the EGTC Regulation, but this intention failed because the Flemish authorities preferred to cooperate on a less formal basis. In contrast, we think that the EGTC Regulation should be given a chance, especially in transboundary water management, as its general applicability throughout Europe might lead to a more coherent way of and more transparency in transboundary water management within the EU. We do not consider this form of cooperation to be too intense and too formal as no public competences will be assigned to the EGTC (these will remain with the members themselves) and an EGTC is (just) an instrument to jointly implement policy.

\section{Conclusions}

With the adoption of the Water Framework Directive, new approaches have found their way into modern EC water law. A major new approach in EC water law is the river basin approach, dividing water flows into geographically allocated river basins. This approach does justice to the flowing and uncontained character of water, but also lies at the heart of one of the major challenges in water management for the EC and especially for its Member States. In theory, the problem can be captured in a few words: the objectives of the EC water directives have to be met by the Member States individually, while the river basin approach leads to shared responsibilities between Member States within a river basin. Or even more succinctly: to meet their own obligations, Member States should cooperate. In practice, though, transboundary cooperation often seems problematic. The main problem with transnational cooperation is the fact that Member States have different systems and governmental responsibilities for water management. In some Member States water management is part of environmental management, in other Member States it is a separate policy field. Moreover, competent authorities can be found for aspects of water management on the central level, the federal level, the regional level like provinces and the local level like municipalities. For example, in France and the Netherlands there are specific water authorities. In other Member States water management is not dealt with by the government alone, but also by agencies or private organizations.

${ }^{104}$ See Van Rijswick [27], pp. 99-100. 
Cooperation in transboundary water management should take place on both the international and the regional level. The former level is mostly suitable for inter alia the coordination of the implementation of $\mathrm{EC}$ water directives and the coordination of river basin management plans and programmes of measures. The latter is better suited to executing water policy in practice. Cooperation at state level mostly takes place within the setting of Treaties. There are less legal problems when only Member States are parties. Arrangements can be more far-reaching and include water quality, water quantity, flood protection, protection of the marine environment and so on.

Cooperation at a regional level mostly takes place in an informal way because of a hesitation to use binding legal arrangements, because of differences in the organization of water management within the Member States, the way Member States deal with complexity and policy discretion and perhaps also because of a different sense of urgency and differences in culture. Also the ambitions to meet objectives deriving from these directives differ among Member States, as do the ways in which these states consider the legal value of obligations. Eliminating, minimizing or at least mutually understanding these differences should be the starting point for Member States wishing to cooperate successfully.

A really new approach would be to hold all Member States that together share a river basin district responsible for achieving the goals and objectives. That wouldat least in our opinion-lead to closer cooperation and to a restricted use of exemptions. We expect that in the end the goals and objectives of the new water directives will be attained somewhat earlier, because there is also a shared sense of urgency. Furthermore, it is a more logical approach, which fits better in transnational river basin management. The problem is, of course, that EC environmental law uses directives with obligations for Member States individually. Putting forward these changes would mean a revision of the EC Treaty and many water directives. However, the idea deserves further investigation.

Open Access This article is distributed under the terms of the Creative Commons Attribution Noncommercial License which permits any noncommercial use, distribution, and reproduction in any medium, provided the original author(s) and source are credited.

\section{References}

1. AcW/CAW: Bruggen bouwen, Nederlands waterbeheer in Europees en grensoverschrijdend perspectief, November 2007. www.cawsw.nl

2. AcW/CAW: Grensoverschrijdend Waterbeheer in Nederland, Verkennend onderzoek ten behoeve van AcW/CAW, March 2007. www.cawsw.nl

3. CAW: Samenwerking over grenzen: relatie tussen Europese Kaderrichtlijn Water en internationale verdragen, The Hague (2004)

4. Costa, L., Vergés, J.C., Barraqué, B.: Shaping a new Luso Spanish convention, Working Paper no. 08/2008, Universidade Católica Potuguesa, Porto (2008)

5. Dieperink, C., Glasbergen, P.: Het beheer van onze internationale rivieren, Lessen uit de ontwikkeling van de Rijn-, Maas- en Scheldecommissies. In: Van Hall, A., Drupsteen, Th.G., Havekes, H.J.M. (eds.) De Staat van Water, Opstellen over Juridische, Technische, Financiële en Politiek-bestuurlijke Aspecten van Waterbeheer, pp. 45-49. Koninklijke Vermande, Lelystad (1999)

6. Gilissen, H.K.: Internationale en regionaal grensoverschrijdende samenwerking in het waterbeheer, The Hague (2009). www.sdu.nl

7. Heemskerk, W.F.A.: Waterrecht en Waterschapsrecht, Het grenswater de Roer/die Rur, Utrecht (1985) 
8. Hertoghs, M.W.J.A.: De grens in je achtertuin. In: Faure, M., Peeters, M. (eds.) Grensoverschrijdend Recht, p. 112 ff. Intersentia, Antwerp-Oxford (2006)

9. Hertoghs, M.W.J.A., Hoetjes, B.J.S.: Bijeenbrengen, verbinden en wakker houden, Het functioneren van de bestuurlijke samenwerkingsverbanden over de Nederlandse grens, Maastricht (2002)

10. Hey, E., Van Rijswick, H.F.M.W.: Transnational water management. In: Jansen, O., SchöndorfHaubold, B. (eds.) The European Composite Administration. Intersentia (forthcoming)

11. Howarth, W.: Aspirations and realities under the water framework directive: proceduralisation, participation and practicalities. J. Environ. Law, Advance Access published July 2 (2009)

12. Keessen, A.M., Van Kempen, J.J.H., Van Rijswick, H.F.M.W.: Transboundary river basin management in Europe, Legal Instruments to comply with European water management obligations in case of transboundary water pollution and floods. Utrecht Law Rev. 35-56 (2008). www.utrechtlawreview.org

13. Krämer, L.: Thirty Years of EC Environmental Law: perspectives and prospectives. In: Somsen, H. (ed.) Yearbook of European Environmental Law, vol. 2. Oxford University Press, London (2002)

14. Lee, M.: EU Environmental law, Challenges, Change and Decision-making. Hart Publishing, Oxford and Portland (2005)

15. Maes, F., Lavrysen, L. (eds.): Integraal Waterbeleid in Vlaanderen en Nederland. Die Keure, Bruges (2003)

16. Maia, R.: The EU Water Framework Directive implementation in the Iberian context (2008). www. worldwatercongress2008.org

17. Ministerie van Binnenlandse Zaken: Benelux-overeenkomst grensoverschrijdende samenwerking, Den Haag (1992) [Dutch Ministry of Internal Affairs: Benelux Agreement on transboundary cooperation, The Hague (1992)]

18. Nollkaemper, P.A., de Villeneuve, C.H.V.: Recht van internationale waterlopen. In: Horbach, N., Lefeber, R., Ribbelink, O. (eds.) Handboek Internationaal Recht. T.M.C. Asser Press, The Hague (2007)

19. Peeters, M.G.W.M.: The Joint Governance of Transboundary River Basins-Some Observations on the Role of Law, Maastricht (2008)

20. Reinhard, S., Folmer, H. (eds.): Water Policy in the Netherlands, Integrated Management in a Densely Populated Delta, Issues in Water Resource Policy. RFF (Resources for the Future) Press, Washington (2009)

21. Scott, J.: Flexibility, proceduralization and environmental governance in the EU. In: de Burca, G., Scott, J. (eds.) Constitutional Change in the EU. From Uniformity to Flexibility? Hart Publishing, Oxford and Portland (2000)

22. Seerden, R.: Publiekrechtelijke grensoverschrijdende samenwerking tussen Nederlandse decentrale overheden en hun 'counterparts' in België en Duitsland. MAKLU Uitgevers, Antwerp (1993)

23. Seerden, R.: Waar een juridische weg is, is niet altijd een bestuurlijke wil. In: Faure, M., Peeters, M. (eds.) Grensoverschrijdend Recht, p. 12 ff. Intersentia, Antwerp-Oxford (2006)

24. Solf, S.: Europäisches Flussgebietsmanagement und Deutsche Wasserwirtschaftsverwaltung, Zur Rechtlichen Umsetzung des Art. 3 Wasserrahmenrichtlinie. Erich Schmidt, Berlin (2006)

25. Uijen, R.W.J.M.: Euregio's-Van idealistische organisaties tot spellers op de bestuurlijke kaart van Europa. In: Spoormans, H.C.G., Reichenbach, E.A., Korsten, A.F.A. (eds.) Grenzen over, Aspecten van Grensoverschrijdende Samenwerking, pp. 82-92. Uitgeverij Coutinho, Bussum (1999)

26. Uitenboogaart, Y., Van Kempen, J.J.H., Wiering, M., Van Rijswick, H.F.M.W. (eds.): Dealing with Complexity and Policy Discretion, A Comparison of the Implementation of the Water Framework Directive in Five Member States. Sdu Uitgevers, The Hague (2009). www.sdu.nl

27. Van Rijswick, H.F.M.W. (ed.): EG-recht en de praktijk van het waterbeheer, [EC law and water management in practice], Utrecht (2009)

28. Van Rijswick, H.F.M.W.: Moving Water and the Law, on the Distribution of Water Rights and Water Duties within River Basins in European and Dutch Water Law. Europa Law Publishing, Groningen (2008)

29. Wellman, G.: Legal Aspects of Transboundary River Pollution in the Carpathian Basin, a case study of the Hungarian approach to protect the Tisza and the Rába rivers, Utrecht University (2009) 